\section{The enemy of science is within}

SIR - John Maddox's puzzlement (Nature 378, 435-437; 1995) at the generalized public distrust of science should be pursued. If Democritus's assertion (a cornerstone of Baconian science), that all things occur according to natural law or by chance were to permeate the public understanding, some interesting things might happen. For example, the trivial television series Star Trek would fail to appeal to a public forearmed with a belief in the tidiness of thermodynamics. The myth of miracles and the almost universal doctrine of supernatural intervention would be recognized as intoxicating folklore, and limiting population in the interests of the environment might become possible. The resurgence of vitalism in the 'natural' food industry, where much of society believes that a radish nourished on manure is preferable to one treated to ammonium nitrate, would also be due for an overhaul.

It seems to me that the public distrust of science is mostly due to the abject failure of scientists to make the case that we live in a material Universe. Scientists have engaged in a peculiar apostasy in dividing their beliefs of science on the one hand and succumbing to ethnic and cultural fantasies or, to paraphrase some popular wisdom, (1) if science has an enemy, it is us, and (2) if we are not part of the solution, we are the problem.

\section{Cecil H. Fox}

Molecular Histology Inc., 18536 Office Park Drive, Gaithersburg, Maryland 20879, USA

SIR - I am in sympathy with Maddox's comments about "the prevalent distrust of science". To me the centrepiece of the article is the phrase that "to represent the nature of human beings by a description of their genes undermines their dignity as human beings" and that "research in human genetics" is therefore to be opposed.

Despite its brevity, this statement glows with misapprehensions and unreflected prejudices, and it is this cocktail of stupidity that is the actual poison. To evoke as an antidote, as it were, the benefits that people enjoy as the results of scientific endeavour is useless labour, because these benefits constitute a category different from, and so irrelevant to, the categories of misapprehension and prejudice.

Hope, if there is any, rests with enlightenment alone. But does Maddox really believe that church (in fact, and so to speak, his Commentary's last word) is the place where the light will eventually shine? To me it appears to be the place where people are indoctrinated with pre- conceptions about "the nature of human beings" that are ultimately baseless and consequently do not help us at all when it comes to solving the problems of our time. Helmut Grünewald

Hauptstrasse 58,

D-95369 Untersteinach,

Germany

SIR - Maddox provides an example of why distrust of science persists. If the contribution of science were as one-sided and positive as he suggests, such distrust might be hard to understand. However, given that science is done by humans within a cultural and historical context and usually reflects the values of the culture, the argument that only the positive results count is naive. A glance at the history book should provide sobering detail of science in the service of death and destruction. The rosy misrepresentations Maddox provides are worthy of our distrust.

\section{Stephen Keast}

Cornell University,

Ithaca,

New York 14853, USA

SIR - Maddox makes several suggestions as to how the worrying trend towards public distrust of science can be reversed. He rightly stressed the importance of scientists not overstating the implications and value of their work and of the need to make the public more aware of how the scientific process works. He also recognized how science can appear to be a threat to those with deeply held religious beliefs, and challenged those of us who are both scientists and 'religious' to play our part in showing the fallacy of such fears.

The point is well taken, and there are many of us who find opportunities within the church and other religious communities to do just this. But there is an equal responsibility for scientists to avoid making unnecessary and intolerant attacks on religious belief. If the impression is given by some scientists that religious belief must conflict with the scientific view of the world, it should be no surprise that many in the population, for whom religious belief is a real and vital experience, distrust science and scientists. Those who seek to preach a 'gospel of science' that opposes religious belief are more likely to accentuate any distrust of science in the majority of the population than they are to convert others to atheism.

\section{Andrew P. Halestrap}

Department of Biochemistry,

School of Medical Sciences,

University Walk,

Bristol BS8 1TD, UK
Confidentiality of referees

SIR - In his valediction, John Maddox (Nature 378, 521; 1995) raises "the problem of the implied confidentiality [of referees]". The solution to this problem is clear: eliminate it. Since its inception 15 years ago, Cell Calcium has requested referees to sign their reports. I can recall only a handful of occasions when a referee has declined to act because of this stipulation.

While Cell Calcium is clearly not Nature, it is a highly regarded journal. (At the risk of incurring Maddox's wrath by mentioning "yardsticks of attainment", let me say that it has an impact factor of around 5). As co-editor (with Toni Scarpa) of this journal, it is my subjective impression that a requirement to sign a report, while reducing the invective, in no way lowers the scientific rigour of referees who, unable to hide behind unsubstantiated generalizations, are forced to focus on facts. Isn't that what science is all about? I cannot believe that science (or indeed almost anything else) is best served by confidentiality. I therefore find it rather depressing that, after 30 years at the helm of a leading science journal, Maddox still feels that it is important (while admitting that in practice it doesn't exist).

Maynard Case

School of Biological Sciences, University of Manchester, G.38 Stopford Building,

Oxford Road,

Manchester M13 9PT,UK

\section{Family likeness}

SIR - Nicholas Christenfeld and Emily Hill's fascinating analysis of the similarity between young children and their parents showed that babies are recognizably similar to their fathers and apparently less similar to their mothers (Nature 378, 669; 1995). They argue that evolution would select babies who look like their father to reassure the father that the baby is his. That cannot be correct. How would preindustrial fathers know what they looked like? They had no mirrors.

It may be that this signalling system is aimed at the mother, or at other men or women, to tell them that this baby belongs to this man. Or it may be that, in underlying facial morphology as in other matters, men remain more infantile than women.

William Bains

PA Consulting Group,

Cambridge Technology Centre,

Melbourn,

Hertfordshire SG8 6DP, UK 